\title{
Engaging Autobiography: Mobility Trauma and International Relations
}

\author{
Amanda Russell Beattie \\ Lecturer, Aston University \\ Address: Aston Triangle, Birmingham, B4 7 ET UK \\ E-mail: a.r.beattie@aston.ac.uk
}

\begin{abstract}
This article outlines the possibilities of autobiographical stories to criticize status quo iterations of International Relations (IR). The article draws on the personal experiences of the author's deportation order issued by the United Kingdom's Home Office and its associated Border Agency (UKBA) to challenge the accepted assumptions of a cosmopolitan worldview as it relates to orderly international institutional design. It highlights the possibilities of trauma when border management and personal mobility collide. It suggests that mobility trauma ensues when the expectations of human mobility, outlined in Article 13 of the Universal Declaration of Human Rights, infringe the state's role as security provider. It begins in part one with a challenge to the traditional role and understanding of international borders that sustain order within the international. It examines the unacknowledged role that human vulnerability plays within IR and institutional design while frankly engaging with human vulnerability and trauma in the second section. This section details the experiences of the author when her mobility rights were curtailed and the ensuing identity crisis prompted by such events. The final section investigates the ideas of critical cosmopolitan scholarship demanding that such discourses acknowledge and work through the possibility of failed agency when the demands of state security supersede individual mobility rights. It turns to the possibility of traumatic iterations of IR in order to probe such possibilities. The article suggests, in its conclusion, the possibility of storytelling and psychoanalysis to endorse unorthodox agency, and the possibility of a dynamic international institutional design, that challenges the status quo iterations of IR.
\end{abstract}

Keywords: autobiography, international relations, borders, cosmopolitanism, narrative psychoanalysis

I was ordered to be deported from the United Kingdom, and the process unfolded over nine months in 2013. The experience left me feeling helpless, without a voice, unable to access "the political." I could not be an effective agent. As an academic writing within the discipline of International Relations (IR), this experience remains confusing. ${ }^{1}$ It drove me to reflect upon the cosmopolitan worldview I had long championed at a professional and personal level. Cosmopolitanism, very briefly, understands that a common moral humanity, predicated on an assumed shared vulnerability, exists. It contests the primacy of the state, champions the individual moral subject, and eschews violence and conflict. It gestures towards a vulnerable interpretation of being political in common $(\mathrm{Lu}, 2009$; O’Neill, 2000; Erskine, 2000; Kaldor, 2013; Buchanen, Nye, 2004; Held, 1995; Archibugi,

\footnotetext{
() Amanda Russell Beattie, 2014

(c) Centre for Fundamental Sociology, 2014

1. This paper refers to International Relations (IR) as the disciplinary study and international relations (ir) the events and practices that inform the discipline. I draw on Hollis \& Smith (1991) to make this claim.
} 
1993; Held, Archibugi, 1995). Reflecting on this most basic iteration of the cosmopolitan aspiration, in light of being ordered deported, revealed a series of paradoxes that I could not meaningfully process. Cosmopolitanism ought to attend to the harm that emerges when border management and human mobility intersect; however, cosmopolitan practices and structures are complicit in a process of silencing at this very intersection. This, I suggest, is problematic because such silencing furthers, rather than engages with, instances of harm.

This article disrupts the story of assumed human mobility. It demands that if cosmopolitanism really does eschew violence and conflict, and promotes a universal vulnerable subject, it must attend to the harm that such paradoxes reveal. I suggest that the underlying universal assumption of the cosmopolitan worldview renders this task impossible. The idea of the rights-bearing subject, the assumed linearity of trauma and its experiences, and the complicit acceptance of state borders within its institutional design, forecloses the possibility of listening and reflection. ${ }^{2}$ The experience of trauma, I suggest, is non-linear and challenges the spatial and temporal assumptions guiding international institutional design. In order to meaningfully engage with this experience, we must have the space to listen and reflect. Acting in and of itself is neither necessary nor sufficient. Trauma is not experienced and negotiated by the empowered universal ethicist. Working through traumatic experiences can only happen on the timetable of the traumatized person. In order to attend to the idiosyncrasies of mobility trauma in suitably appropriate ways, IR must be flexible, dynamic, and open-ended.

This paper is skeptical of a cosmopolitan worldview, and challenges the universality of its assumptions. It turns to the idea of voice, facilitated by an autobiographical methodology, to investiage the harm that ensues in light of universal assumptions of being human. Part One of this article interrogates the institutional design of IR querying the role that borders play in managing order, and the complicit role of cosmopolitan order therein. Part Two reveals my own experience of human mobility when, in April 2013, I was ordered to be deported from the United Kindgom. It reveals a personal and professional identity crisis that began when I realized that I was not welcome in the UK despite my assumed value as a good democratic citizen. This ordeal highlights the precarious existence of the foreigner within the state. Their transplantation within the political is only successful if it is aligned with democratic institutional iterations of the public good. The ability to render this precariousness to an audience, academic or otherwise, is all but impossible if access to the political is denied. Part Three develops this theme further. It probes the notion of abject cosmopolitanism demanding that critical cosmopolitanism go further and grapple with the possibility of failed agency. The conclusion imagines what can be done in the face of such a failure, and describes the possibilities of narrative and psychoanalytical methods applied to the failed expectations of personal mobility in a global age.

The expectations of mobility articulated in a universal rights discourse and associated with a cosmopolitan world view cannot protect the vulnerable individual from the lived

2. I am drawing on Robert E. Goodin's description of institutional design. He describes this process in The Theory of Institutional Design (1991). 
experience of managed mobility in a global era. Article 13 of the Universal Declaration of Human Rights affirms that all individuals have the right to travel freely. It is a right that is exercised in a variety of ways on a daily basis. A cursory glance at the statistics provided by Heathrow Airport (2014) in the United Kingdom (UK) confirms this. In 2013, 72.3 million people travelled its corridors, the busiest year on record. On any given day, an average of 191,200 people pass through its terminals; on the 3oth of June, 238,949 people did during the busiest day of 2013. This is, I acknowledge, a privileged type of travel. But it is indicative of the ability of a global population to actively engage as mobile people as described in Article 13. This right is curtailed when, for any number of reasons, an individual is denied entry into a state.

Article 13 similarly articulates a right to return home. When this right is taken away from an individual or forced unwillingly on another, their expectations of mobility are curtailed. To "be removed," or to be subjected to forced migration, occurs for many reasons. The United Kingdom Border Agency (UKBA) distinguishes between three categories of removal; deportation, administrative removals, and voluntary departures. It then further distinguishes and defines these terms noting that deportation "applies to people (and the children of such people) whose removal from the country is deemed 'conducive to the public good' by the Secretary of State, or when recommended by a court in conjunction with conviction of a criminal offence punishable by a prison term" (2014). While these terms and their definitions may provide legal clarity to the process of deportation, they do not attend to the particularities of this experience. They do not tell us what events led to the deportation order being issued, nor do they highlight the experiences of the deportee. Instead, the statistics relating to deportation paint a stark picture of a particular political act without giving any insight to its influence or impact on the everyday experiences of being human.

The Migration Observatory at Oxford University reports that of the 320,000 UK émigrés in 2013, 50,741 of those individuals were forcibly removed from the UK. This is a $14.5 \%$ rise in the number of deportations since 2012, and an overall doubling of deportation since 2004. The rise in deportations indicates that the UK government increasingly believes that properly-conceived deportation is an appropriate tool to manage human mobility. Peter Nyers (2003) argues that deportation is not only a policy tool, but also a performative act. To deport a person is an explicit demonstration of the state's sovereign, legitimate power. It recognizes the state as the primary security provider, re-affirms an international order that emphasizes internal order over external anarchy, and the ability of the state to mediate such boundaries.

I do not accept that cosmopolitan assumptions cannot challenge realpolitik lessons of the realist world view, but I acknowledge the pedagogy supporting a realpolitik victory. I am deeply troubled to learn that the cosmopolitan worldview that freely and openly articulates the inherent vulnerability of the global population simultaneously silences those who are enacting their mobility rights. This is especially problematic if the mobile person is a forced migrant seeking out the most basic rights of subsistence and security. A fleeting glimpse at statistics from the United Nations High Commissioner for Refugees 
reveals that millions of people flee war, violent conflict, and persecution every year. In 2013 alone, 51.2 million people were forcibly displaced worldwide. This, they write, "was the highest on record since comprehensive statistics on global forced displacement have been collected" (UNHCR, 2014). These, and the aforementioned, statistics reveal that people are increasingly mobile. They leave one community and seek out another. Regardless of the reasons prompting mobility, the enacting of mobility rights is a clear and growing trend.

As a first step towards a dynamic iteration of IR that meaningfully engages with this trend, I turn to the idea of "the voice." I contend that "the voice" is a necessary addition to the normative and ethical iterations of IR because, as Roxanne Doty writes, it foregrounds issues of inclusion and exclusion, identity and difference, and institutional design. I draw on the emerging trend of an autobiographical methodology within IR and use it in this paper to highlight "the voice." It is one way of imagining alternative encounters with mobility expectations. I turn to the reflexive potential of autobiographical encounters, aware of the emerging community of scholars who champion both autobiography and autoethnography within the discipline ( Bleiker, Brigg, 2010; Lowenheim, 2010; Doty, 2010; Neumann, 2010; Dauphinee, 2010). I am guided particularly by the writings of Naeem Inyatullah (2010). I suggest, as he does, that autobiography provides "a substantive look at life/lives in process" and reveals "the mundane and the dramatic, the empirical and the theoretical, the structures and the processes that constitute and change humans" (Inyatullah, 2010: 7). Autobiography as methodology enhances the idea of mobility trauma. It offers insight into how scholars of IR might better contribute to the understanding of the identified paradoxes of cosmopolitan mobility.

The inclusion of autobiographical methodologies in IR scholarship is radical. It situates the personal and the emotional at the epicenter of an unfolding narrative. Feminist discourses have long advocated a role for "the personal" within the political, and the possibilities of reflexivity within research design (see for example, Ruddick, 1989; Cohn, 1987; and more recently, Ackerly, True, 2008). Feminist encounters with the personal challenge rational explanations and universal structures, providing a greater nuance to research design. Ackerly and True (2008) argue that there is a need to reflect upon the appropriateness of research design when unexpected stories and conclusions surface. The conclusions of Ackerly and True provide alternative imaginings of being political that suggest individuality and idiosyncrasy ought to feature when unorthodox experiences of being political emerge. I suggest, drawing the arguments of Ackerly and True, that autobiography enhances the personal experiences of mobility and security. It creates a space for the voice at the intersection of border management and human mobility.

\section{Borders and Order}

Where the personal expectations of mobility collide with the state's management of mobility, we tend to find a border. Borders are defined in many ways. They have a geographical component that notes the physical limitations and boundaries of the state (Rumford, 
2006). Borders are also central to discussions of world order and institutional design (Rengger, 2001; Suganami, 1989; Waltz, 2001; Mearsheimer, 2001; Ikenberry, 2009; Buzan, 2004; Dunne, 1998). They permeate discussions of forced migration, engage with the labelling of stateless persons, immigrants, asylum seekers, and refugees (Innes, 2014), and influence the discourse of international citizenship (Benhabib, 2004). Borders are also critically examined. For example, Vaugn-Willams and Parker (2009) contest status quo descriptions of borders challenging the underlying assumptions of boundaries, borders, and their reification in IR.

Judith Butler (1990) offers an alternative discussion of borders, or boundaries, in her work Gender Trouble. She highlights the role that borders play in establishing control and social regulation over a subject. While her work is directly related to the self as subject, I suggest her discussion of borders offers much to inform the discipline of IR. For example, she notes the inherent desire for stability associated with the performativity of a border. She also discusses the absolute inability to achieve such stability.

The boundary between the inner and outer is confounded by those excremental passages in which the inner effectively becomes outer, and this excreting function becomes, as it were, the model by which other forms of identity-differentiation are accomplished. In effect, this is the mode by which Others become shit. For inner and outer worlds to remain utterly distinct, the entire surface of the body would have to achieve an impossible impermeability. This sealing of its surfaces would constitute the seamless boundary of the subject; but this enclosure would invariably be exploded by precisely that excremental filth that it fears. (Butler, 1990: 182)

Bulter provides a compelling argument against the possibility of ever achieving impermeability; however, the desire for impermeability, or stability, can be seen within the assumptions of institutional design andIR discourses of order.

As Rengger's (2001) publication on world order and political theory suggests, managed accounts of order invoke borders to distinguish the ideas of inner and outer discussed by Butler. He demonstrates how a particular reading of international sovereignty defines the international. The absence of an overarching legitimate governing authority renders the international anarchic. Borders are the boundaries that both manage and reify anarchy. Borders are, in effect, a cordon sanitaire. This cordon is understood in geographical and spatial representations of the state. What is inside the border is safe, and what is outside that border is a potential threat. Borders, as Margrit Shildrik (2000) argues, are assumed to render "us" safe from the threats of "them." She is critical of this interpretation of boundaries because she, like Butler, is aware of their permeable nature. She provides compelling evidence that the sense of security afforded by such an imaging of borders in fact prompts situations of exile and silencing. Those labelled "other," who do not conform to the status quo, are set outside the political. I suggest that such assumptions permeate traditional accounts of world order. Individuals who should be protected by Article 13 for whatever reason must provide ample evidence of their suitability for 
entry. They must challenge the aura of reasonable suspicion of the foreigner if they want to be admitted into the political.

As Mark B. Salter (2006) has argued in drawing on the ideas of Agamben and Foucault, those who navigate borders are rather abruptly silenced. Salter vividly re-creates that moment when a passenger disembarks from an airplane and then travels the corridors of the airport to finally arrive at a border site. From the point of disembarking until reaching a border, the traveler exists in a state of suspended existence. He or she lacks state representation and protection. This state of suspension lasts throughout the border experience. A traveler is viewed with suspicion; why does he/she wish to gain access? What instability follows if the mobile person gains entry to the political? These are the problems that a border agent tries to deny by holding hostage, on behalf of the government, the rights of mobility of the traveler. A traveler lacks a voice. In essence, anyone who navigates a state border lacks an element of agency throughout this process. Salter's traveler recalls the privileged statistics of Heathrow Airport, where 72.3 million people decide of their own free will to take up the right to travel. For the most part, these individuals pass through border control with ease, provided they have a passport. Their silencing, in effect, ends when they prove their suitability to the public good. This silencing is temporary.

Temporary or otherwise, when the voice of a mobile person is removed, the concept of a border and its management is beyond contestation. The cordon sanitaire remains unharmed and in place because a voice is required to contest the status quo. This silencing achieves two things. It maintains the precarious assumption of impermeability while reifying the harmful labels of "us" and "them." The realities of "inside" and "outside" are starkly revealed. It is here that the expectations of mobility in a globalized world and the management of human mobility are heightened and highlighted. The traveler is an active agent. He/she is actualizing the expectations of mobility as articulated in Article 13 of the Universal Declaration of Human Rights. It re-affirms the right to move and reside within "the borders of each state," and also the right to leave and return to one's country of origin. But with each border crossing, the realities of border management are experienced. The traveler is subject to what Salter identities as the "confessional experience." Not only must they produce the required documentation, the traveler must also disclose any information demanded by the border agent. Here a voice is allowed to speak. The voice is not an idiosyncratic expression of agency, but is rendered complicit in the elusive quest for controlled permeability.

There is also evidence that suggests an-altogether more harmful silencing that is happening to the forced migrant. Liisa Malkki's $(1995,1996)$ ethnographic fieldwork in Rwanda and Burundi reveals how silencing is complicit in the experience of mobility. Malkki's silencing was not facilitated in the absence of the rule of law as noted by Salter (2006). The silencing she witnessed emerged within the structures of international humanitarian aid. While in Rwanda, she noticed a trend whereby the particular stories and life experiences of the exiled were expunged. The voices of displaced persons were silenced. The particularities of violent conflict, of the loss of one's homeland, and of the 
idiosyncrasies of war could not overcome the impersonal rendering of the human rights subject, the international humanitarian regime, and the over-arching liberal interpretations of international order. To have a story, or to be a person with wounds (physical and/ or ontological), was not part of the overarching narrative of being an exile. She labels this experience as "corporeal anonymity." Maalki's fieldwork reveals that the structures that articulate a universal right to mobility and shape the expectations of mobility also silence those who need access to the political. She notes how this silencing begins, how it is upheld, and what the experience of such silencing can be like for an exile. The experience of corporeal anonymity poses very real problems for the cosmopolitan discourse. In its most general sense, cosmopolitanism defends the vulnerable and imagines a world united in moral solidarity. What Malkki's work reveals, however, is that its framework is unable to attend to the needs of the vulnerable migrant.

In her publication, The Rights of Others (2004), Seyla Benhabib, a noted cosmopolitan writer, deals directly with this problem. She contests the relationship of borders, political membership, and migration. She begins her discussion with an account of political membership. It is "the principles and practices for incorporating aliens and strangers, immigrants and newcomers, refugees and asylum seekers into existing polities" (Benhabib, 2004: 1). Mobility, she writes, is encapsulated in the discourse of citizenship; however, she wonders if citizenship is fit for purpose. She, like myself, queries how philosophical and empirical discussions might begin to mediate the relationship of state sovereignty and mobility rights. She wonders where rights within this relationship might feature, if at all. Benhabib qualifies how and why someone might find themselves excluded from a given political community. She addresses the struggles associated with such negotiations, which she calls democratic iterations. They are, she writes, "those complex processes of public argument, deliberations and exchanges through which universalist rights claims are contested and contextualized, invoked and revoked, positioned and repositioned, throughout legal and political institutions, as well as in the associations of civil society" (Benhabib, 2004: 179).

Benhabib approaches this discussion in a discursive fashion. Her framework reminds her readers that the role of the philosopher, in this case, is to separate the political from the moral and the social. The philosopher must look at the relationship of the universal and the particular as a series of mediations and negotiations. By making such distinction, we are able to move the discussion of citizenship from a vicious debate to a virtuous discussion. She then goes on to say (Benhabib, 2007: 451), in a rebuttal to Aleinikoff (2007), that she is "less interested in justifying the finality of closure but more in the circulation of normative issues and questions throughout the public spheres and civil societies of democracies, and beyond their borders, such as to enable the democratic conversation to continue despite decisional closure." Benhabib's work assumes an ongoing conversation. This ongoing discussion is facilitated by empowered agents. This, I suggest, is a limitation. It does not imagine a space where the disenfranchised might contribute meaningfully to the iterative process or how they might contribute at all in the absence of a voice and access to the political. 
The philosopher is the primary agent in Benhabib's iterative process. This agent not only has a voice but it also has access to the political. I wonder if this voice is best suited to the task at hand. The cosmopolitan philosopher championed by Benhabib enjoys a position of privilege. Kimberly Hutchings (2013) comments on this privilege when she questions the reflexive abilities of the universal ethicist. In a publication centered on the possibilities of vulnerability in IR, Hutchings asks the reader to wonder at the type of harm that might ensue if the universal ethicist is unable to empathize with the suffering other. A double harm could emerge whereby the original suffering remains unaddressed, and, in fact, further enhanced simply because the cosmopolitan scholar, situated within a universal framework of assumed order and morality, is unable to realistically engage with the suffering other. The universal ethicist is unable to be actively reflexive. This is because the structures of the cosmopolitan worldview do not entertain the possibility of listening. These structures inherently assume a universal human experience. Harm and trauma, I suggest, are idiosyncratic and defy universal experience. How then can the universal philosopher or cosmopolitan agent attend to such suffering? In short, they most likely cannot.

At the same time, within a democratic iteration, there is no point when the exiled other can meaningfully engage as an agent. Such iterations assume access to the political, and the silencing of the exiled other prohibits such engagement. If we recall the original claims of Butler (1990) and Shildrick (2000), such individuals are situated outside the political because they are deemed a threat. Malkki (1996) provides an explanation for the type of threat they pose. She problematizes the humanitarian regime which assumes that one is only moral or can acquire moral knowledge if they live within a state. Without a state, in the absence of a family, or a motherland, the migrant is unable to understand the expectations of good citizenship. They are, in effect, a threat to the stability and order of "the political" of their new country. The literature that is part and parcel of the cosmopolitan discourse and which should support those outside the political, suggests that to willingly choose to leave one's home community and build a life elsewhere is pathological. This assumption is a direct challenge to the right of return articulated in Article 13. The pathological label delegitimizes the lived experience of the forced migrant. Their stories challenge the assumed impermeability of borders and the universality of being human.

Forced migrants are positioned beyond the democratic responsibilities of the modern state and simultaneously denied access to the political. They are, in this institutional design, powerless. I suggest that the idiosyncratic experiences of mobility could inform Benhabib's concepts in ways unavailable to the cosmopolitan philosopher. Such information could provide compelling information on the need to re-visit citizenship, and the way that borders manage mobility in a global age. In their current condition, borders do not facilitate the stability and protection of the global population as articulated within cosmopolitan discourses. In fact, the literature suggests an increased number of migrants being turned away, and therefore, an increase of suffering. The current desire for secure, or impermeable, borders is structurally reprehensible, and certainly traumatic personally. 


\section{Working through the Threat of Deportation}

My story is one of unenforced deportation. At times, it aligns with the ideas of forced migration, at times it does not. Likewise, at times, it evokes, as Edward Said has written, an exiled subjectivity (2001). What I acknowledge explicitly is this: it is not the only story to emerge when mobility rights, and the expectations they sustain, collide with border management in a global world. It may be representational of a larger experience, but at the same time, it might not. This article does not seek to fill an entire gap that exists in understanding the plight of the forced migrant. To do so would run counter to the challenges put forward throughout this article. Rather, in telling my story, I illustrate the power of "the voice" when it is able to be heard. There is a need to engage at a personal level in IR. Albeit biased, actual experiences, both personal and emotional have much to offer to the discourses of IR in general, and cosmopolitanism in particular. This is the importance of "the voice." It affords a space for anyone's story if they want to tell it. It facilitates a space where others can listen. It imagines a space outside "the political" where agency, unorthodox as it may be, can establish itself.

I was ordered deported from the United Kingdom in 2013. On 18 April, 2013, I was waiting for the return of my Canadian passport from the UKBA. What I thought would be a delivery returning my passport turned out to be a registered letter informing me that my work permit application had been rejected. I had seven days to appeal the decision, or 28 days to leave the country. I am a Canadian citizen, but a resident of the UK. I have lived in the UK for 12 years. I arrived in 2002 as a graduate student on the required student visa. When this expired after my PhD in IR was completed, I applied for a Fresh Talent Scotland Visa for one year. That led to a Highly Skilled Migrant Workers Visa in 2008 when I applied for and received a lectureship in Politics and International Relations at Aston University in Birmingham, UK. This visa expired on 18 February, 2013. I sent my renewal application to the UKBA on February 1, with little fear of refusal. Not only am I a good democratic citizen with ties to the community, I was also married to a British citizen and had two children, ages 8 months and almost 3, who are British by birth. My own arrogance allowed me to believe that deportation was something that happened to someone else, not me. I was a highly skilled migrant. I am the type of person that governments wanted to have in the country, or so I thought. I was wrong in my assumption.

Perhaps, you are wondering, why I did not seek British Citizenship, or perhaps, why not apply for a spousal visa? I qualify for both. The answers are not that simple, however, but are framed in a variety of discourses. At a very practical and financial level, my husband and I believed our family would be more secure if I applied for a work permit. I am the primary income earner in the family. It is my permanent job that allows us to hold a mortgage, have access to solid and reputable financial investments, and provide for our children in a responsible fashion. In essence, a spousal visa and family visa require the marriage unit to remain intact. Should it dissolve, the foreign party is required to leave the country. In other words, the possibilities of a relationship breakdown and dissolution render me a flight risk in the eyes of financial institutions. In choosing to remain as an 
independent worker, we thought that our children would be better protected, and our independence, autonomy, and financial well-being would remain secure. Yet again, we were wrong.

I recognize that my experience of deportation unfolded in relative comfort. I was allowed to stay with my family throughout the entire process. Our daily lives continued in a routine fashion. I went back to work when my maternity leave ended. The boys kept going to their nursery, and my husband continued working at his job. We were, in all accounts, materially provided for. Not only did we have food, shelter, and a variety of goods providing varying levels of comfort, we also had support during the appeal process itself. Institutionally, the University helped fund the appeal. We had a solicitor prepare our appeal arguments, and a barrister who argued them at the immigration tribunal. I did not face language and learning barriers like others in my own situation, a point poignantly rendered to me as I sat waiting to write the "Life in the United Kingdom" test, a necessary part of becoming a permanent resident and citizen. Moreover, we had childcare provisions on the day of the appeal itself. This was something we took for granted, and only realized our privileges while sitting in the waiting room watching other families arrive with up to five children in tow.

I might, rather flippantly suggest, that our experience is/was very much a \#firstworldproblem!

What I now understand is this; the numbing sensation I felt when reading the deportation order was the beginning of a traumatic experience. I faced an identity crisis. I could not put into words what we were experiencing as a family. I was terrified that I would be separated from my husband and children. But my terror went beyond that. How could I provide for them if I didn't have a job? I am the primary (but not sole) income earner in the family. Our mortgage depends on my salary. What would we do if we lost our house? How could I keep the children safe? Where would we get the money to buy our weekly groceries? These might seem like trivial problems, but these were some of the questions that plagued us as a family from April to December as we awaited the outcome of the immigration appeal. These were the practical elements of my trauma. When we found out that I could stay in the UK they dissolved in an instant.

On the other hand, aspects of this traumatic event remain with me. When I discovered I was under the threat of deportation, I felt a deep rejection. I felt that I was not good enough. I did not align with the public good as interpreted by the Home Office. The rejection wasn't simply political. It was also exceptionally personal. Having abandoned one way of negotiating the world only to build it anew on cosmopolitan principles, I began to wonder if, yet again, I got it wrong. For the first time, I felt that the cosmopolitan principles I embraced reading Martha Nussbaum's (2001) The Fragility of Goodness might not fulfill the promises I thought they had. Nussbaum's work offers an account of being human that can attend to both the contingent nature of life in common while articulating an account of moral agency and the common good. Nussbaum outlines the role that luck plays in everyday life and, at times, the tragic nature of being human. She recounts not only that goodness is something that must be cultivated and developed, but also that hu- 
man beings, through no fault of their own, will experience harm and suffering. The role that she assigns to emotions in softening the brutality of the social and political world is telling. Not only does it reveal the centrality of vulnerability in our daily lives and how fragile life is, but that even in the face of the uncontrollable and the contingent, people as agents can try and rise above it.

Nussbaum's world is both beautiful and brutal. I understood, in the idea of the moral cosmopolitan agent, a way of engaging the world that articulated responsibility coupled with moral agency and practical reason. It did not suggest a relational account of obligations and duties. The motivation to act in a morally appropriate fashion, guided by kindness and not opportunity, is a way of being part of a community. One is accountable to the community through one's own shared values and ideals that measure one's actions and reactions. In such communities, one can make mistakes, provided one learns from them. If one can acknowledge hurt, or bad luck, and work with those harmed, aware of the underlying kindly motivations, one can learn as a community how best to move forward. Perhaps I am personally unlucky. I chose to trust the wrong people to help me with the visa renewal process. Equally, perhaps I had assumed (wrongly it transpired) that the UKBA might demonstrate elements of common sense when they noticed the mistakes in the application by my sponsoring institution.

There is a reflexive element to my previously constructed worldview. When harm is experienced, or unintended consequences malign the common good, agents revisit the decisions they made and wonder if, in the future, alternative modes of agency would have been more appropriate. I struggle to find evidence of such reflexivity within cosmopolitan principles. The universality underpinning cosmopolitan iterations of IR do not soften the unwelcome experience of deportation. The agent within that worldview could not help me navigate that experience. I could not realistically communicate what I was going through, but perhaps even more problematically, the recipient agent did not know what questions to ask that could help them to more clearly understand the situation. In fact, I wonder if a philosophical cosmopolitan agent would think to ask a question fullstop. There was, and remains, an absence of reflection or reflexive capabilities within the cosmopolitan agent. I believe it is this absence of reflection that maintains the anxiety and unease I continue to feel when I now work through what it is to endorse a cosmopolitan approach to global politics. I struggle to understand how I can use this framework to shed light on the nature of borders, especially in the absence of responsible agency and reflexivity. I worry that it cannot attend to the harm that follows when mundane matters of law result in the (potential) separation of friends, families, and communities.

I do feel shame for imagining that I might be above the politics of mobility, that others, but not me, had cause to worry. This flies in the face of the cosmopolitan worldview I previously endorsed. If we are all morally worthy, then we should all be equally vulnerable to humanity's creations. Certain portions of the global population should not be more precariously placed than others. Perhaps even worse, my previous publication (Beattie, $2008,2013)$ actually deals with vulnerability in IR. The same year I was ordered deported, I suggested (2013) that we needed greater nuance and application of the concept to enrich 
our understanding of the suffering other within the global world. That I could argue this point, all the while adopting the universal moral assumptions of the natural law tradition, now makes me cringe. I cringe because I could not realize, from my position of privilege, the universalizing ontology of the tradition marginalizing the personal stories of being human. I regret such claims, and now, rather oddly, find myself grateful for having the experience of being ordered deported. It shattered my privileged worldview and made me aware of the greater harms that universal assumptions can provoke. However, I make this statement many months after the practical elements of my trauma have come to a close.

I have lost a sense of security and purpose in the wider world. This is equally scary and painful. I genuinely do not know if that sense of security and ease within the world will ever return. But I am not sure that I would have it back given the opportunity. I'm not sure I can mourn the loss of my previously held cosmopolitan sensibilities. I believe my anxiety and fear facilitate the ability to listen and wonder in the first instance instead of rushing in to act. I do not believe I have a greater understanding of the forced migrant, or the insecurities their own story reveals. But the pathology of being unwelcome prompts a newfound empathy and a desire to understand the plight of others. The inherent value of trauma is that it remains with me always. It situates me in the present and demands that I engage in the moment. It forces me to acknowledge the little details. What is significant to my construction of IR is that it differs from what it once did. I am attuned to the personal. I have a desire to now listen to the stories of others and understand what renders them simultaneously terrified and courageous in the face of the unknown and unpredictable.

\section{Beyond Abjection}

In "Abject cosmopolitanism: the politics of protection in the anti-deportation movement" (2003), Nyers wonders if in eschewing conflict and war and attending to a wider vulnerability open to the possibilities of friendship and hospitality, cosmopolitanism fails to acknowledge, in an appropriate manner, those who sit outside the political. He wonders if and when such individuals challenge the legitimacy of the state, or disrupt the political, what impact that challenge has on the state and the wellbeing of the abject. Abjects, he notes, are "increasingly classed as the objects of securitised fears and anxieties, possessing either an unsavory agency (i.e., they are identity-frauds, queue jumpers, or people who undermine consent in the polity) or a dangerous agency (i.e., they are criminals, terrorists, or agents of insecurity)" (Nyers, 2003: 1070). He engages with these labels wondering if it is possible to incorporate the subjects of de-connection and often-violent detachment within the state into a broadly construed discussion of cosmopolitanism.

He turns to the works of Paul Ranciere (2004), and Bonnie Honig (2009), to engage with what he describes as "the abject." The "abject cosmopolitan(s)" that Nyers identifies are the refugees and immigration groups challenging their own specified exclusions, and the associated political practices and/or problems that can emerge: 
The abject is someone who is cast-out, discarded and rejected. In contrast to the vaunted status of cosmopolitanism, the abject are held in low regard as outcasts. While the cosmopolitan is at home everywhere, the abject have been jettisoned, forced out into a life of displacement. When considered together, therefore, the "abject" and the "cosmopolitan" appear as stark contrast, relating to one another only in highly oppositional terms; high/low, hope/despair, beautiful/ugly, belonging/exclusion, everywhere/nowhere. (Nyers, 2003: 1073)

In essence, the abject stand as the opposition to the good democratic citizen. This being said, the abject are agents. Drawing on the writings of Nikolas Rose (1999), Nyers reminds the reader that to be abject, or to be subject to abjection, is an act of force. Furthermore, he, like Judith Butler (1993: 3), suggests that such positionings are, in actual fact, a means of repositioning the struggle to "re-articulate the very terms of symbolic legitimacy and intelligibility." In actual fact, in his discussions of abject agency, we can actually begin to see the very important role that lived experience and personal appeals can and do play in attending to both the harm and trauma of mobility.

While governments around the world are moving to a system of tighter border controls, there is also a series of coordinated protest movements against such policies and practices. As Nandita Sharma (2003) describes them, "no border movements" coalesce around a series of shared goals. They are committed to the free movement of people and the end to displacement on a global scale. They likewise support indigenous land claims and the right to self-determination. Nyers (2003: 1084) builds on these ideas in his examination of the work that the Non-Status Refugees Action Committee (CASS) has done to limit the deportation of its migrant community:

These meetings usually include forcing officials to read the individuals case files and hear the testimonies of the refugee claimants. This is the key advantage of delegation visits: they allow for face-to-face encounters with state officials invested with enormous powers of discretion. As one member of CASS complained, "We are treated as file numbers, not as human beings." Once the compelling individual stories behind these numbers are shared, it is not unusual for immigration staff to be moved to tears.

In their work, we can identify tactics that disrupt administration, the routines, and the "normality of deportations." They support delegation visits. These tactics give a voice to those traditionally rendered "abject" or voiceless. Nyers's account of agency is compelling. He is able to allocate powers of the agent to those traditionally rendered voiceless, and to those who are cast as suspicious and threatening. His work is a serious improvement on the cosmopolitanism advanced by Benhabib (2004, 2007). He attends to the need for empowerment, the problematics of global institutional design, and an inherently natural mobile ontology. Yet, I suggest he has not gone far enough. While he envisions a role for agency, he does not attend to the possibility of failure. The potential for trauma that ensues in the face of a deportation order, never mind its actual implementation, remains real and unaddressed. 
When I refer to trauma or traumatic experience, I am drawing on a wide range of scholars, some located within IR, and others who sit outside the formal disciplinary boundaries. As Jenny Edkins (2002: 245) writes, trauma, or traumatic events, "involves an exposure to an event so shocking that our everyday expectations of how the world works are severely disrupted." Traumatic events involve a sense of betrayal, a loss of trust, and a shattering of one's world view. Trauma, as Crossely (2000) writes, unmakes our world. Perhaps most problematic for the mimetic practices of IR and borders therein is that the events of trauma do not conform to standard unfoldings of history, time, and space. Traumatic events are, as Edkins (2002) writes, non-linear. While one can distinguish the life before and after the traumatic event, a point nicely outlined by Gemignani (2001) in his work on trauma and migration, at the point of trauma itself, the agent is rendered silent. This is most likely the case because in the face of trauma individuals speak to a numbing sensation, an inability to express the unfolding experience(s) in words or acts.

The experience of trauma forces individuals to come face-to-face with the vulnerability that frames philosophical cosmopolitanism. I suggest that such encounters with vulnerability are curtailed if, and when, they challenge the potential for impermeable borders. As my own experience revealed, being a good democratic citizen, assuming that I was a key player in the wider global community, could not and did not provide me with the tools to navigate this particular vulnerability. To be rendered silent, when trauma occurs, is an understood phenomenon. Rather interestingly, in my own shock and silence, I found solace in the aforementioned luck discussed by Nussbaum (2001) in as much as bad things can happen through no fault of one's own. It is how we move forward that is telling. I could re-assert some power in my daily activities, acknowledging the lack of power I experienced because of the failed work permit application while simultaneously taking comfort in the fact that how I reacted to this determination was an indication of the person I believed I was, a global cosmopolitan citizen.

At the moment of trauma, this helped. As I began to work through this experience in the upcoming months, however, it was increasingly unhelpful because I could not find a place therein for my own therapeutic rendering of my shattered worldview. Trauma is both unpredictable and idiosyncratic, and because of this, it does not align with universal technical constructions of aid. Such agents are imbued with an obligation and responsibility to help others. But the timetable that outlines when and how help is secured is very much at the behest of the empowered agent, and not the individual experiencing trauma. This is the experience of corporeal anonymity discussed by Malkki (1996). Simply stated, the cosmopolitan would help at the moment of the traumatic experience. In that silence, the experience of numbing, when little information is available on the nature of harm being experienced, the agent would act regardless of whether or not it was the most appropriate moment.

The idiosyncratic nature of trauma, its inability to be rendered controllable and set within a timetable, poses problems for IR, in general, and cosmopolitanism, in particular. As Kate Schick (2009: 147-148) argues in her thinking through of trauma and the ideas of Adorno, the therapeutic needs of the traumatized individual do not align with the 
universal, technical knowledge of a liberal ethical approach to addressing past harm and avoiding it in the future:

The concrete other, passed over in the pursuit of universal guidelines for living, is often the individual experiencing the negative aspects of progress and is precisely the one who suffers in silence. Although a desire to emancipate humankind from suffering provides the motivation for mainstream international ethics, this suffering is too quickly passed over in the attempt to delineate universal norms, and the influence of present emotion or past traumas on present capability for political interaction is all but ignored.

The moment when the traumatized agent is able to acknowledge and work through the harm experienced is unpredictable and unexpected. Personally, it was not until the ordeal was finished that I was able to begin to work through the events and the impact they had on our lives. Only in the secure knowledge that I was staying in the UK could I meaningfully address the underlying fear and insecurity that had navigated my life, and the lives of my family, throughout most of 2013. The security that I required in order to analyze the experience and its underlying identity crisis that ensued did not materialize at the moment of trauma, but rather 13 months later. Furthermore, the nature of support that I needed, as well as the length of time I needed to work through all of these events, remains highly personal. Not only are the stories of forced migration idiosyncratic, but so are the ways in which the agents works through the events and seek to rebuild their lives, although with a heightened sense of their vulnerability in a global world. This type of therapeutic process requires those offering aid to be highly attuned to the specificity of the experience. In other words the process of working through, or therapy, is not easily universalized.

In rendering the cosmopolitan agent abject, and reminding us that not all experiences are the same and that one must be mindful of creating a universal, identifiable other, Nyers (2003) has gone further than most in offering a voice to those who experience the negative aspects of forced migration. His identification of storytelling within the CASS strategy is telling in that regard. It empowers the abject at that moment in time, facilitating a space within which the story can emerge. This is but one moment in the experience of forced migration. It does not encapsulate the entirety of the deportation ordeal. Nyers draws on the experiences of non-status Algerian persons in Canada. His 2002 telling of their story does not reflect the original need to flee, the insecurity of the mobile experience, nor the uncertainty once arriving in Canada. While it does hint at the ongoing ordeal within the state, it does not speak to the impact this experience has had on the personal aspects of being human. More is needed to attend to the holistic experience of forced migration and the impact it has on the relational and social components of being human. In order to make this claim with sufficient force and impact, the Conclusion gestures to the need for a narrative framework within which autobiography and story-telling take on a meaningful role in the repositioning of the agent within a vulnerable global world. 


\title{
Conclusion
}

In the works of David Carr (1986), the relationship between time and narrative experience is thoughtfully presented, and the possibilities of a narrative approach are revealed. He argues, drawing on the ideas of Husserl, that life experiences can mirror the structure of narrative or story-telling. He argues that life is not a series of monochromatic events unrelated to each other, but rather like music notes in a symphony; they only gain relevance and understanding when situated alongside the note played before and after. Carr argues that in our actions, we can identify plot development, structure, and narrative. These framings of our stories can be experienced actively and passively. He writes that "The narrative grasp of the storyteller is not a leap beyond time but a way of being in time. It is no more alien to time than the curving bands are alien to the river or the potter's hands to the clay" (Carr, 1986: 89). What emerges then is an altogether alternative experiencing of life events that are given meaning not only by past histories, but by present reflection as well. If we return to the opening claims of this article and reflect meaningfully on the ideas put forward by Inyatullah (2011), we can further reinforce the claim that authentic voice, rendered personal and vulnerable, can play both effective and affective roles in revealing the structures and process of the political.

Drawing on Carr (1986), Crossely (2000) argues on behalf of a narrative approach to engage with the specificities of traumatic experiences. In her opinion, telling stories, or telling one's own story, allows for the agent to begin to make sense of the newfound traumatic world, and slowly begin the task of aligning their temporal and spatial experience with the practices of the political:

\begin{abstract}
Literary stories such as fiction and autobiography do not in any sense "impose" a structure and order on human action and life. Instead, they tend to reinforce and make more explicit the symbolisation that is already at work within a culture at the level of practical human action. The function of narratives such as autobiographies, then, is simply to reveal structures or meanings that previously remained implicit or unrecognised, and thus to transform life and elevate it to another level. (Crossely, 2000: 537)
\end{abstract}

It is to begin again the task of engaging within the political. It is within these relationships and experiences that the human story, the vocalizing of shared histories can, and does, emerge. As she writes, "we have a sense of who we are through a sense of where we stand in relation to "the good" (Crossely, 2000: 533). The possibility of narration facilitates a return of one's ontological security. One is able to construct anew the relationship that the self has within the community, but in particular, to access the underlying account of the good around which both political and social relationships coalesce.

Crossley indicates the therapeutic potential of narrative and psychoanalysis. She displays many affinities to the critiques noted by Schick (2009), and Edkins (2002), in the attendant problems of suffering in a liberal worldview. She writes that narrative "appreciates the linguistic and discursive structuring of "self" and "experience" but also maintains 
a sense of the essentially personal, coherent and real nature of individual subjectivity" (Crossely, 2000: 530). She is referring to the elusive "concrete other" noted by Schick, while reiterating the challenge of Edkins (2002) that therapy does not exist to reinsert one's self in the previously held worldview. Therapy deconstructs the status quo stories informing the personal, the awareness of our shared vulnerabilities, and the ongoing insecurity that is revealed when such stories are found wanting. We do not engage in such practices to re-insert ourselves in a world that has let us down. Instead, there is a concerted effort to work through the event and to shore up strength in the hopes of negotiating the world as it is, in its fully unpredictable and hopeful way. In essence, it is to tell, and re-tell the traumatic experience, to shore up personal strength, and work through the space in between.

The traumatized agent is beginning the task of rebuilding relationships, of situating themselves in time, as suggested by Carr (1986). They are re-asserting their agency on their own terms, defining what tools they need to assimilate such experiences. They are, as Crossely (2000) writes, seeking out relationships. I suggest further that these agents are rebuilding their communities. I am influenced in this suggestion by the writings of Elizabeth Dauphinee (2010). She argues on behalf of ontological communities instead of epistemic communities. Such ontological communities, she writes, "involve a certain alchemy and a commitment to understanding our worlds as spaces of opportunity for creation and fruitful debate that seek not to destroy the ideas and risks we might be willing to take, but instead foster them" (Dauphinee, 2010: 817). How might a mobile agent begin such a task?

As Gemangini (2011) has revealed in his work with refugees and undocumented migrants, the past is part and parcel of the phenomenological experience of the migrant story. One cannot disavow this experience, but rather engage with it to work through and re-align new and emerging ideas of the self and other within the community. Telling one's story, and the creation of the space for autobiography, can sustain such practices. In the aftermath of being ordered deported, I lost my way and my story, along with my identity, was critically examined. I do not suggest that I have found the path that I want to follow, but in seeking to understand my experience, I found the experience of trauma meaningful and useful. I take to heart what Ellis (2004) writes when she notes that scholars, prompted by "a knock," can reflect and write about such instances. These "knocks," I suggest, bear a similarity to the communal or personal traumatic experiences discussed throughout this article.

I tried to find reasons for why I was ordered to be deported, but none were forthcoming. I found solace in the writings of Edkins (2002). Her investigation of 9/11 reminds readers that security, war, and conflict may be the dominant security story in IR. She labels this approach "securitization" and identifies it as the chief response of government and policy makers to the events of $9 / 11$. Her argument, however, is this: even though securitization remains the dominant approach, or story, of IR, it is not the only story. Societies can choose, if they wish, to be political in other ways. She reminds the reader that societies choose what stories to tell and which stories define them. She endorses an account of 
politicization, not securitization. This story begins with reflection, it prompts learning, and suggests negotiation as a means of engaging with others within (and beyond) the political. Politicization challenges the universality of security and heavy-handed action. In being aware of this point, I suggest that the stories of permeable and impermeable boundaries are told with reference to the idea of securitization highlighted and criticized by Edkins. They highlight the problems created when mobility is managed in such a way that it violates the expectations agents have of a right to be mobile.

As I present my position within a variety of communities, and seek to re-establish relationships as discussed by Crossely (2000), I am aware of the need for permeable boundaries, and the precarious misbelief of impermeability in an age when people actively take up the right to be mobile. I am likewise aware of the need for my voice to help interrogate and reflect upon the suffering that impermeability fosters. It is for this reason that I emphasize both lived experience and voice throughout this paper. It imagines alternative forms of agency that might influence the political from outside its boundaries, but also invites others to engage. I do so fully aware of Edkin's (2002) iteration of politicization contra securitization, and the possibility of a dynamic, open-ended vision of the international fostered by the lived experience of others.

\section{Bibliography}

Ackerly B., True J. (2008) Reflexivity in practice: power and ethics in feminist research on international relations. International Studies Review, vol. 10, no 4, pp. 693-707.

Aleinikoff T. A. (2007) Comments on the rights of others. European Journal of Political Theory, vol. 6, no 4, pp. 424-430.

Archibugi D. (1993) The reform of the UN and cosmopolitan democracy: a critical review. Journal of Peace Research, vol. 30, no 3, pp. 301-315.

Archibugi D., Held D. (eds.) (1995) Cosmopolitan Democracy: An Agenda for a New World Order, Cambridge: Polity Press.

Beattie A. R. (2008) Obligations of Love: International Political Thought and the Tradition of Natural Law (PhD Dissertation), Scotland: University of St. Andrews.

Beattie A. R. (2013) Only in the Leap from the Lion's head Will He Prove His Worth': Natural Law and International Relations. Journal of International Political Theory, 9,1, 22-42.

Benhabib S. (2004) The Rights of Others: Aliens, Residents, and Citizens, Cambridge: Cambridge University Press.

Benhabib S. (2007) Democratic exclusions and democratic iterations: dilemmas of just membership and prospects of cosmopolitan federalism. European Journal of Political Theory, vol. 6, no 4, pp. 445-462.

Brigg M., Bleiker R. (2010) Autoethnographic international relations: exploring the self as a source of knowledge. Review of International Studies, vol. 36, no 3, pp. 779-798.

Buchanan A., Keohane R. O. (2004) The preventive use of force: a cosmopolitan institutional proposal. Ethics and International Affairs, vol. 18, no 1, pp. 1-22. 
Butler J. (1990) Gender Trouble: Feminism and the Subversion of Identity, New York: Routledge.

Butler J. (1993) Bodies that Matter: On the Discursive Limits of "Sex," New York: Routldege.

Buzan B. (2004) From International to World Society?: English School Theory and the Social Structure of Globalization, Cambridge: Cambridge University Press.

Carr D. (1986) Time, Narrative, and History, Bloomington: Indiana University Press.

Cohn C. (1987) Sex and death in the rational world of defense intellectuals. Signs, vol. 12, no 4 , pp. $687-718$.

Crossley M. L. (2000) Narrative psychology, trauma and the study of self/identity. Theory \& Psychology, vol. 10, no 4, pp. 527-546.

Dauphinee E. (2013) The Politics of Exile, New York: Routledge.

Dauhpinee E. (2010) The ethics of autoethnography. Review of International Studies, vol. 36, no 3, pp. 799-818.

Doty R. L. (2004) Maladies of our souls: identity and voice in the writing of academic international relations. Cambridge Review of International Affairs, vol. 17, no 2, pp. 377392.

Doty R. L. (2010) Autoethnography: making human connections. Review of International Studies, vol. 36, no 4, pp. 1047-1050.

Dunne T. (1998) Inventing International Society: A History of the English School, Basingstoke: Macmillan.

Edkins J. (2002) Forget trauma? Responses to September 11. International Relations, vol. 16, no 2, pp. 243-256.

Erskine T. (2000) Embedded cosmopolitanism and the case of war: restraint, discrimination and overlapping communities. Global Society, vol. 14, no 4, pp. 569-59o.

Gemingnani M. (2011) The past if past: the use of memories and self-healing narratives in refugees from the former Yugoslavia. Journal of Refugee Studies, vol. 24, no 1, pp. 132156.

Goodin R. (1996) The Theory of Institutional Design, Cambridge: Cambridge University Press.

Heathrow Airport. (2014). About Heathrow Airport. Availabe at: http://www.heathrowairport.com/about-us/company-news-and-information/company-information/ facts-and-figures (accessed 1 December 2014).

Held D. (1995) Democracy and the Global Order, Cambridge: Polity Press.

Hollis M., Smith S. (1991) Explaining and Understanding International Relations, Oxford: Clarendon Press.

Honig B. (2009) Democracy and the Foreigner, Princeton: Princeton University Press.

The Home Office. (2014) Policy Paper. Immigration Rules. Part 13: Deportation. Available at: https://www.gov.uk/government/uploads/system/uploads/attachment_data/ file/364804/20141020_Immigration_Rules_-_Part_13.pdf (accessed 21 October 2014).

Hutchings K. (2013) A place of greater safety?: securing judgement in international ethics. The Vulnerable Subject (eds. A. R. Beattie, K. Shick), Basingstoke: Palgrave Macmillan, pp. 25-42. 
Inayatullah N. (ed.) (2010) Autobiographical International Relations, New York: Routledge.

Ikenberry G. J. (2009) After Victory: Institutions, Strategic Restraint, and the Rebuilding of Order after Major Wars, Princeton: Princeton University Press.

Innes A. (2014) Performing security absent the state: encounters with a failed asylum seeker in UK. Security Dialogue, vol. 45, no 6, pp. 565-581.

Kaldor M. (2013) New and Old Wars: Organised Violence in a Global Era, Cambridge: Polity Press.

Lowenheim O. (2010) The "I" in IR: an autoethnographic account. Review of International Studies, vol. 36, no 4, pp. 1023-1045.

Lu C. (2009) Political friendship among peoples. Journal of International Political Theory, vol. 5, no 1, pp. 41-58.

Malkki L. H. (1995) Refugees and exile: from" refugee studies" to the national order of things. Annual Review of Anthropology, vol. 24, pp. 495-523.

Malkki L. H. (1996) Speechless emissaries: refugees, humanitarianism, and dehistoricization. Cultural Anthropology, vol. 11, no 3, pp. 377-404.

Mattern J. (2005) Ordering International Politics: Identity, Crisis and Representational Force, New York: Routledge.

The Migration Observatory at the University of Oxford (2014) Deportations, Removals and Voluntary Departures from the UK. Available at: http://www.migrationobservatory.ox.ac.uk/briefings/deportations-removals-and-voluntary-departures-uk (accessed 10 October 2014).

Neumann I. B. (2010) Autobiography, ontology and autoethnology. Review of International Studies, vol. 36, no 4, pp. 1051-1055.

Nussbaum M. (2001) The Fragility of Goodness: Luck and ethics in Greek Tragedy and Philosophy, Cambridge: Cambridge University Press.

Office for National Statistics (2013) Migration Satistics Quarterly Report, November 2013. Available at: http://www.ons.gov.uk/ons/rel/migration1/migration-statistics-quarterly-report/november-2013/msqr.html (accessed 1o October 2014).

O’Neill O. (200o) Bounded and cosmopolitan justice. Review of International Studies, vol. 26, no 5, pp. 45-6o.

Parker N., Vaughn-Williams N. (2009) Lines in the sand?: towards an agenda for critical border studies. Geopolitics, vol. 14, no 3, pp. 582-587.

Ranciere J. (2004) Disagreement: Politics and Philosophy, Minneapolis : University of Minnesota Press.

Rengger N. (2000) International Relations, Political Theory and the Problem of Order: Beyond International Relations, London: Routledge.

Rose N. (1999) Powers of Freedom: Reframing Political Thought, Cambridge: Cambridge University Press.

Rumford C. (2006) Introduction: theorizing borders. European Journal of Social Theory, vol. 9, no 2, pp. 155-169. 
Said E. (2001) Reflections on Exile: And Other Literary and Cultural Essays, London: Granta Books.

Salter M. B. (2006) The global visa regime and the political technologies of the international self: borders, bodies, biopolitics. Alternatives: Global, Local, Political, vol. 31, no 2 , pp. 167-189.

Sharma N. (2003) No borders movements and the rejection of left nationalism. Canadian Dimension, vol. 37, no 3, pp. 37-40.

Schick K. (2009) "To lend a voice to suffering is a condition for all truth": Adorno and International Political Thought. Journal of International Political Theory, vol. 5, no 2, pp. 138-16o.

Shildrick M. (2000) Becoming vulnerable: contagious encounters and the ethics of risk. Journal of Medical Humanities, vol. 21, no 4, pp. 215-222.

Suganami H. (1989) The Domestic Analogy and World Order Proposal, Cambridge: Cambridge University Press.

UNHCR (2014) War's Human Cost. Available at: http://www.unhcr.org/5399a14f9.html (accessed 10 October 10 2014).

UN (1948) Universal Declaration of Human Rights, 10 December 1948, 217 A (III). Available at: http://www.refworld.org/docid/3ae6b3712c.html (accessed 1 December 2014).

\title{
Привлекая автобиографию: травма мобильности и международные отношения
}

\author{
Аманда Расселл Битmи \\ Преподаватель Астонского университета \\ Адрес: Aston Triangle, Birmingham, B4 7ET UK \\ E-mail: a.r.beattie@aston.ac.uk
}

Автор предлагает использовать автобиографическую методологию для анализа травматического опыта депортации. В статье делается предположение, что травма мобильности возникает, когда принципы свободного перемещения людей, зафиксированные в Статье 13 Всеобщей декларации прав человека, вступают в противоречие с ролью государства в обеспечении безопасности. Для описания этого опыта автор анализирует автобиографический опыт депортации. В частности, пересматриваются космополитические представления и показывается, как они поддерживают миф о непроницаемых границах государств, и одновременно замалчиваются взгляды тех, кто подвергает этот миф сомнению. В заключение автор описывает роль повествования и психоанализа в поддержке критической повестки и возможность существования гибкого международного институционального устройства, которое бы пересматривало статус кво в практиках международных отношений.

Ключевые слова: автобиография, международные отношения, границы, космополитизм, нарративный психоанализ 